\title{
RESEARCH
}

Open Access

\section{Large-diameter trees, snags, and deadwood in southern Utah, USA}

\author{
James A. Lutz ${ }^{1 *}$ D, Soren Struckman ${ }^{1}$, Tucker J. Furniss ${ }^{1}$, Joseph D. Birch², Larissa L. Yocom ${ }^{1}$ and Darren J. McAvoy ${ }^{1}$
}

\begin{abstract}
Background: The epidemic Dendroctonus rufipennis (spruce beetle) outbreak in the subalpine forests of the Colorado Plateau in the 1990s killed most larger Picea engelmannii (Engelmann spruce) trees. One quarter century later, the larger snags are beginning to fall, transitioning to deadwood (down woody debris) where they may influence fire behavior, regeneration, and habitat structure.

Methods: We tracked all fallen trees $\geq 1 \mathrm{~cm}$ in diameter at breast height (1.37-m high) and mapped all pieces of deadwood $\geq 10-\mathrm{cm}$ diameter and $\geq 1 \mathrm{~m}$ in length within 13.64 ha of a high-elevation mixed-species forest in the Picea-Abies zone annually for 5 years from 2015 through 2019. We examined the relative contribution of Picea engelmannii to snag and deadwood pools relative to other species and the relative contributions of large-diameter trees ( $\geq 33.2 \mathrm{~cm}$ at this subalpine site). We compared spatially explicit mapping of deadwood to traditional measures of surface fuels and introduce a new method for approximating vertical distribution of deadwood.

Results: In this mixed-species forest, there was relatively high density and basal area of live Picea engelmannii 20 years after the beetle outbreak ( 36 trees ha ${ }^{-1}$ and $1.94 \mathrm{~m}^{2} \mathrm{ha}^{-1} \geq 10-\mathrm{cm}$ diameter) contrasting with the near total mortality of mature Picea in forests nearby. Wood from tree boles $\geq 10-\mathrm{cm}$ diameter on the ground had biomass of $42 \mathrm{Mg} \mathrm{ha}^{-1}, 7 \mathrm{Mg} \mathrm{ha}^{-1}$ of Picea engelmannii, and $35 \mathrm{Mg} \mathrm{ha}^{-1}$ of other species. Total live aboveground biomass was $119 \mathrm{Mg} \mathrm{ha}^{-1}$, while snag biomass was $36 \mathrm{Mg} \mathrm{ha}^{-1}$. Mean total fuel loading measured with planar transects was 63 $\mathrm{Mg} \mathrm{ha}^{-1}$ but varied more than three orders of magnitude $\left(0.1\right.$ to $\left.257 \mathrm{Mg} \mathrm{ha}^{-1}\right)$. Planar transects recorded $32 \mathrm{Mg} \mathrm{ha}^{-1}$ of wood $\geq 7.62-\mathrm{cm}$ diameter compared to the $42 \mathrm{Mg} \mathrm{ha}^{-1}$ of wood $\geq 10-\mathrm{cm}$ diameter recorded by explicit mapping. Multiple pieces of deadwood were often stacked, forming a vertical structure likely to contribute to active fire behavior.

Conclusion: Bark beetle mortality in the 1990s has made Picea an important local constituent of deadwood at 20$\mathrm{m}$ scales, but other species dominate total deadwood due to slow decomposition rates and the multi-centennial intervals between fires. Explicit measurements of deadwood and surface fuels improve ecological insights into biomass heterogeneity and potential fire behavior.
\end{abstract}

Keywords: Cedar Breaks National Monument, Dendroctonus rufipennis, Utah Forest Dynamics Plot, Vertical fuel structure

\footnotetext{
* Correspondence: james.lutz@usu.edu

'Department of Wildland Resources, S. J. and Jessie E. Quinney College of

Natural Resources, Utah State University, 5230 Old Main Hill, Logan, UT

84322-5230, USA

Full list of author information is available at the end of the article
}

\section{Springer Open}

(c) The Author(s). 2021 Open Access This article is licensed under a Creative Commons Attribution 4.0 International License, which permits use, sharing, adaptation, distribution and reproduction in any medium or format, as long as you give appropriate credit to the original author(s) and the source, provide a link to the Creative Commons licence, and indicate if changes were made. The images or other third party material in this article are included in the article's Creative Commons licence, unless indicated otherwise in a credit line to the material. If material is not included in the article's Creative Commons licence and your intended use is not permitted by statutory regulation or exceeds the permitted use, you will need to obtain permission directly from the copyright holder. To view a copy of this licence, visit http://creativecommons.org/licenses/by/4.0/. 


\section{Introduction}

In temperate forests, bark beetle attacks and fire are two dominant ecological processes which often interact, and these processes may both become more frequent with warming temperatures (Bentz et al. 2010). The spruce bark beetle (Dendroctonus rufipennis Kirby) outbreak on the Colorado Plateau in the 1990s (DeRose et al. 2013) was responsible for considerable mortality of Picea engelmannii. In stands dominated by Picea engelmannii, mortality was commonly $95 \%$ (and up to $99 \%$ ) of stems $\geq 10$-cm diameter at breast height (DBH; DeRose and Long 2007, 2012a, 2012b), but mortality in stands with high proportions of other species has been understudied. This extensive Picea engelmannii mortality is responsible for a pulse of deadwood (down woody debris) that is starting to accumulate on the ground. This large quantity of new deadwood will have far-reaching implications for carbon storage, habitat structure, regeneration, and potential fire behavior within these forests.

The impacts of wildfires in recent years have provoked a great deal of public concern, and mitigating fire severity has become a top priority for managers among many western forests (especially those affected by bark beetle outbreaks). The rapid rise in deadwood associated with snagfall may contribute considerably to future extreme fire behavior (e.g., longer flame length, greater crown fire potential) either overall or in discrete patches of high deadwood accumulation. Whether deadwood in forests with high levels of beetle-induced mortality should be reduced mechanically (i.e., by salvage logging) remains a pressing concern. Removal of snags may reduce fire risk but also reduce or eliminate ecosystem function (Janisch and Harmon 2002; Lutz and Halpern 2006; Thorn et al. 2020). Previous work in other forest types has shown that the results of salvage logging can sometimes increase fuel loads (i.e., Donato et al. 2006) and sometimes reduce subsequent fire risk (i.e., Povak et al. 2020).

Furthermore, our understanding of how spatial heterogeneity in trees, snags, and deadwood drives fire behavior is limited. Fire behavior is intricately linked to the total amount, size distribution, and the spatial arrangement of fuels (Miller and Urban 2000). Twodimensional spatial patterning may be captured by a variety of field methods, but the three-dimensional spatial structure (i.e., stacking) of fuels is much more difficult to measure. The three-dimensional arrangement of fuels is particularly important to understanding potential fire behavior (Loudermilk et al. 2012; Hiers et al. 2009; Pimont et al. 2016; Jeronimo et al. 2020) as fuel mass and structure influence the physical process of combustion (combustion rate and efficiency) as well as crown fire potential (greater with higher flame lengths and a more continuous canopy). A variety of field methods have been used to quantify three-dimensional fuel structure and relate this to observed fire behavior (e.g., Hudak et al. 2020), but existing methods (LiDAR and three-dimensional bulk density sub-plots) are labor intensive, and it is difficult to obtain complete coverage of large study areas; in this study, we demonstrate an alternative method.

Deadwood contributes to ecological processes in addition to surface fuel dynamics (Harmon et al. 1986; Thorn et al. 2020). Between snagfall and deadwood's eventual decomposition or combustion (Stenzel et al. 2019), it contributes to biodiversity by changing the microenvironment (Vrška et al. 2015), serving as substrate for seedlings and bryophytes (Taborska et al. 2015) and regulating carbon cycling dynamics (Harmon et al. 1986; Privetivy et al. 2018; Harmon et al. 2020). Because of the differential effects of large-diameter trees, snags, and deadwood on forest structure (Lutz et al. 2012; Lutz et al. 2013; Réjou-Méchain et al. 2014), it is important to specifically consider the effects and dynamics of larger pieces (sensu Lutz and Halpern 2006), rather than adopting an approach that ignores piece size.

As forest cover and fire behavior are patchy and decomposition is slow on the Colorado Plateau, deadwood can remain on the ground for centuries or millennia, causing beetle-mediated mortality events to be ecologically influential for long time periods. Although all pieces of deadwood contribute to fuel loading, the largest pieces contribute disproportionally. In a global study, Lutz et al. (2018) found that approximately half the aboveground live biomass was contained in the largest $1 \%$ of trees. One of our objectives was to extend this analysis to the deadwood to estimate what proportion of deadwood was from the largest trees. We also wanted to specifically examine the deadwood component contributed by the beetle-killed Picea. Our spatially explicit dataset allowed us to answer the following questions about large-diameter deadwood in Picea-Abies forests of Utah:

1) What is the distribution, spatial orientation, and spatial variation in biomass of standing snags and deadwood $\geq 10$ - $\mathrm{cm}$ diameter?

2) What proportion of the current snag and deadwood biomass is Picea engelmannii?

3) How do spatially explicit calculations of deadwood compare with traditional planar sampling methods?

\section{Materials and methods}

\section{Description of study site}

The Utah Forest Dynamics Plot (UFDP; Furniss et al. 2017, Bishop et al. 2019) is a 15.32-ha plot subdivided into a $20 \mathrm{~m} \times 20 \mathrm{~m}$ grid located at a mean elevation of $3081 \mathrm{~m}$ in the mixed subalpine forests of Cedar Breaks National Monument, UT, USA (Cedar Breaks; Fig. 1). 


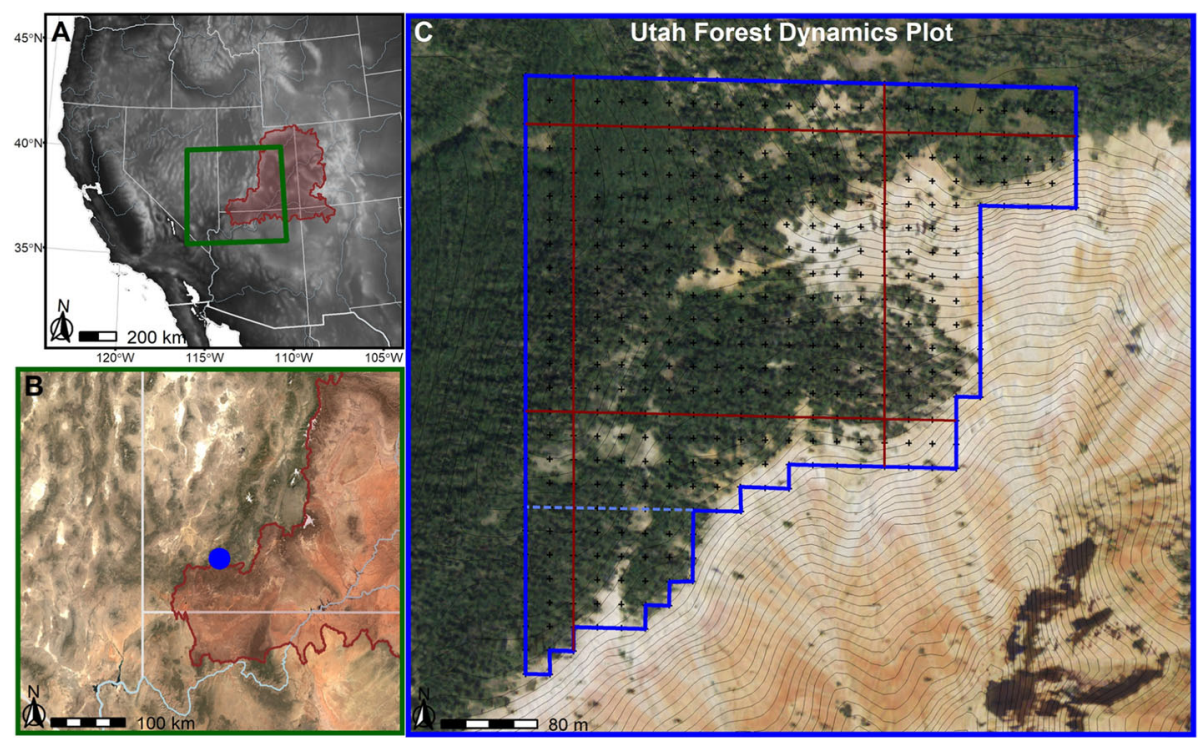

Fig. 1 The Utah Forest Dynamics Plot (UFDP) is located in the Colorado Plateau ecoregion of the Intermountain West of North America (a). The high elevation (mean, $3081 \mathrm{~m}$ ) results in cooler temperatures and higher precipitation than in the lower elevation portions of the Great Basin (b). The UFDP encompasses 15.32 ha (blue outline, of which, 13.64 ha analyzed here) and features a surveyed 20-m grid (c), with planar Brown's transects measured along red lines (c). Panel a digital elevation model shows shading from the Shuttle Radar Topography Mission (2000); panel c topographic lines are a 5-m digital elevation model derived from LIDAR (2018). Shading in panel $\mathbf{b}$ is from a composite of Landsat 8 scenes (2014-2020). The orthophoto in panel $\mathbf{c}$ is from USDA National Agricultural Imagery Program (NAIP) data (2018)

Table 1 Number of live stems and basal area of woody species $\geq 1 \mathrm{~cm} \mathrm{DBH}$ in 13.64 ha of the Utah Forest Dynamics Plot in 2019

\begin{tabular}{|c|c|c|c|c|c|c|c|}
\hline \multirow[t]{2}{*}{ Species } & \multirow[t]{2}{*}{ Family } & \multicolumn{2}{|c|}{$\mathrm{DBH} \geq 1 \mathrm{~cm}$} & \multicolumn{2}{|c|}{$\mathrm{DBH} \geq 10 \mathrm{~cm}$} & \multicolumn{2}{|c|}{$\mathrm{DBH} \geq 33.2 \mathrm{~cm}$} \\
\hline & & Stems & BA $\left(\mathrm{m}^{2}\right)$ & Stems & BA $\left(\mathrm{m}^{2}\right)$ & Stems & $\mathrm{BA}\left(\mathrm{m}^{2}\right)$ \\
\hline Abies bifolia & Pinaceae & 17,326 & 163.54 & 3973 & 142.99 & 356 & 48.87 \\
\hline Populus tremuloides & Salicaceae & 2705 & 90.13 & 1870 & 89.34 & 213 & 23.15 \\
\hline Picea engelmannii & Pinaceae & 1225 & 25.07 & 449 & 23.55 & 77 & 12.61 \\
\hline Pinus flexilis & Pinaceae & 873 & 42.16 & 441 & 41.32 & 150 & 31.6 \\
\hline Pinus longaeva & Pinaceae & 729 & 89.92 & 519 & 89.49 & 279 & 80.44 \\
\hline Picea pungens & Pinaceae & 426 & 29.63 & 260 & 29.3 & 125 & 24.63 \\
\hline Juniperus communis & Cupressaceae & 172 & 0.03 & 0 & 0 & 0 & 0 \\
\hline Ribes cereum & Grossulariaceae & 74 & 0.01 & 0 & 0 & 0 & 0 \\
\hline Pseudotsuga menziesii & Pinaceae & 31 & 1.78 & 14 & 1.74 & 8 & 1.52 \\
\hline Abies concolor & Pinaceae & 14 & 0.48 & 6 & 0.46 & 3 & 0.38 \\
\hline Cercocarpus ledifolius & Rosaceae & 9 & 0.05 & 3 & 0.05 & 0 & 0 \\
\hline Pinus edulis & Pinaceae & 8 & $\mathrm{t}$ & 0 & 0 & 0 & 0 \\
\hline Juniperus scopulorum & Cupressaceae & 3 & 0.08 & 2 & 0.08 & 0 & 0 \\
\hline Amelanchier alnifolia & Rosaceae & 1 & $\mathrm{t}$ & 0 & 0 & 0 & 0 \\
\hline Pinus ponderosa & Pinaceae & 1 & 0.1 & 1 & 0.1 & 1 & 0.1 \\
\hline Ribes montigenum & Grossulariaceae & 1 & $\mathrm{t}$ & 0 & 0 & 0 & 0 \\
\hline Total & & 23,598 & 442.98 & 7538 & 418.42 & 1212 & 223.30 \\
\hline
\end{tabular}

Separate tabulations for abundance of stems $\geq 10 \mathrm{~cm}$ DBH allows comparison with other datasets, and the tabulation of stems $\geq 33.2 \mathrm{~cm}$ DBH indicates those trees above the large-diameter threshold (those large trees constituting half the biomass of the forest) $t$ trace, $<0.01 \mathrm{~m}^{2}$ 
The UFDP is characterized by long, cold winters and short growing seasons. Situated above a 750-m deep natural amphitheater, the site exhibits strong local winds year round. Located in the Picea-Abies vegetation zone, the forest has a mixed species complement including widespread Populus tremuloides as well as the regionally rare, but locally abundant, Pinus longaeva (Table 1).

The fire regime of forest types found in the UFDP is one of infrequent ( $>100$ years median fire return interval) mixed-severity fire (Romme et al. 2009; Heyerdahl et al. 2011). The presence of long-lived (> 1000 years old) Pinus longaeva indicates that there were considerable contiguous areas of low-severity or unburned fire refugia (sensu Kolden et al. 2012, Meddens et al. 2018a) as well as smaller refugia associated with rock outcrops (Kolden et al. 2015; Meddens et al. 2018b; Blomdahl et al. 2019). Dendrochronological analysis of establishment dates for shade-intolerant Pseudotsuga menziesii (Freund et al. 2014) and mass establishments of Abies bifolia, Picea engelmannii, and Populus tremuloides suggest that the last extensive fire in the UFDP was circa 1802. However, given the number of trees older than 200 years, the high-severity portions of the fire must have been patchy. Prior to that, establishment dates of the oldest living Abies bifolia, Picea pungens, and Pseudotsuga menziesii suggest a previous widespread fire in the late 1590s. Dendrochronological analysis of traumatic resin ducts in living Picea engelmannii and lower growth rates of Picea engelmannii versus other tree species indicate that the most extensive bark beetle attack on trees that remained alive in the UFDP was in 1999 (we did not analyze increment cores from trees that died prior to 2018). Other disturbances (aside from the Dendroctonus rufipennis outbreak of the 1990s) include periodic frost defoliation and other species of endemic bark beetles set amid the processes of post-fire succession (i.e., DeRose and Long 2007, 2012a; Birch et al. 2019a, 2019b; Furniss et al. 2020). Dendroclimatological analysis of Pinus longaeva from the UFDP confirms the region-wide extensive drought circa 1250-1345 (Cook et al. 2007). Plant nomenclature follows Flora of North America (1993+).

\section{Data collection}

Within the UFDP, all trees, shrubs, and snags $\geq 1 \mathrm{~cm}$ DBH were identified, measured, mapped, and tagged in 13.64 ha of the plot from 2014 to 2015 according to the protocols of the Smithsonian Forest Global Earth Observatory network (ForestGEO; Anderson-Teixeira et al. 2015, Lutz 2015, Lutz et al. 2018b). The UFDP was divided into $20 \mathrm{~m} \times 20 \mathrm{~m}$ quadrats, with corners surveyed by total stations, and all trees, snags, and deadwood were referenced to the surveyed grid. Subsequent to plot establishment, each of the 23,268 original trees and 4387 snags were visited each year (2016-2019; demographic data in Table S1) to check for mortality and snagfall. New recruitment was also recorded. We measured the diameter and height of each new snag.

Within the UFDP, deadwood originating from the main stems of trees $\geq 10$-cm diameter (both newly fallen in 2016-2019 and those pieces on the ground in 2015) was also mapped and assessed for decay class according to the Smithsonian ForestGEO deadwood protocol (Janík et al. 2018). This deadwood protocol, designed for angiosperm and gymnosperm species, facilitates comparison of deadwood among forests worldwide. Snags and deadwood are divided into five different decay classes that are congruent with existing studies of biomass and carbon content of the different decay classes (Harmon et al. 2008, 2013, 2020). See Janík et al. (2018) for protocol details and Lutz et al. (2020) for an example application in temperate forests.

Deadwood was tracked two ways, depending on tree diameter. For trees $\geq 10-\mathrm{cm}$ diameter at the previous measurement, each piece of the main bole $\geq 1$-m long was mapped, and pieces shorter than $1 \mathrm{~m}$ were ocularly combined with adjacent pieces. Length and diameter at both ends were measured (see Janík et al. 2018 for measurement details). Trees were considered to be fully "fallen" if the remaining stump height was $<1.37$-m high. Otherwise, deadwood was mapped as the "broken top" of a standing snag. For trees and shrubs $1 \mathrm{~cm} \leq \mathrm{DBH}<$ $10 \mathrm{~cm}$, the year of snagfall was recorded, but the smaller stems were not mapped and were assumed to have fallen as a single piece.

\section{Distribution, volume, and biomass calculations}

The biomass of live trees was calculated using equations selected from Chojnacky et al. (2014) and other sources (Brown 1976; Brown 1978; Halpern and Lutz 2013; Jenkins et al. 2003; Means et al. 1994; see Table S2 for listing of equations). We examined all available allometric equations that we could find for species within the UFDP and morphologically similar species, and we selected those that most closely represented growth form of trees at this high-elevation site. This was particularly important for pines (i.e., Brown 1978), as genus-level biomass equations were developed to perform well for large-statured Pinus species (such as Pinus ponderosa), and this would grossly overestimate biomass for shortstatured Pinus in the UFDP (sensu Lutz et al. 2017a, 2017b). We verified the biomass values calculated by our selected equations with biomass estimates derived from volume and density calculations made from field measurements of intact deadwood (Fig. S1A). Many allometric equations for tree species have lower diameter limits (often ca. $3 \mathrm{~cm} \mathrm{DBH}$ ) that do not encompass our full data range, leading to very low (or even negative) 
biomass estimates for trees $1 \mathrm{~cm} \leq \mathrm{DBH}<3 \mathrm{~cm}$. We accordingly set minimum biomass values for smalldiameter stems of the most common tree species as follows: Populus tremuloides and Sambucus racemosa250 g; Abies, Juniperus, Pseudotsuga, Pinus edulis, and P. ponderosa-300 g; Picea engelmannii and Picea pungens-400 g; and Pinus longaeva and Pinus flexilis-500 $\mathrm{g}$, and other shrub species-100 g (Table S2, Figure S1B). With the selected equations, we calculated biomass and determined the large-diameter threshold-the diameter cutoff that divides aboveground live biomass into two equal portions-a large number of small-diameter trees constituting half the biomass, and a much smaller number of large-diameter trees constituting the other half (sensu Lutz et al. 2018).

For snags that died relatively recently (decay class 1 or 2) and were still intact (first-order branches present, bark intact, and top diameter $\leq 10 \mathrm{~cm}$ ), we estimated biomass with live tree equations and corrected with the species- and decay-class-specific relative density factors of Harmon et al. (2008). For snags that were in an advanced state of decay or were not intact, their biomass was estimated by modeling their volume as a conic frustum and using species and decay-class-specific density values from Harmon et al. (2008).

For deadwood, biomass was calculated for the entire originating tree and attributed to specific pieces that fell from that tree. This was done by weighting a piece according to its volume as a proportion of the total volume of the tree, including any remaining standing volume. Biomass was then corrected following the methods of Lutz et al. (2020). For pieces that could not be identified, we used an average density value calculated by proportionally weighting the identified pieces from the UFDP data $\left(0.374 \mathrm{~g} \mathrm{~cm}^{-3}\right.$ for decay class $1 ; 0.299 \mathrm{~g} \mathrm{~cm}^{-3}$ for decay class $2 ; 0.255 \mathrm{~g} \mathrm{~cm}^{-3}$ for decay class $3 ; 0.154 \mathrm{~g}$ $\mathrm{cm}^{-3}$ for decay class 4 ; and $0.139 \mathrm{~g} \mathrm{~cm}^{-3}$ for decay class $5)$.

We divided trees, snags, and deadwood into diameter classes $(1 \mathrm{~cm} \leq \mathrm{DBH}<10 \mathrm{~cm}, 10 \mathrm{~cm} \leq \mathrm{DBH}<33.2 \mathrm{~cm}, \geq$ $33.2 \mathrm{~cm}$, and $20 \mathrm{~m} \times 20 \mathrm{~m}$ quadrats) to examine the effects of the Dendroctonus rufipennis outbreak by considering the relative difference between biomass of susceptible (i.e., Picea engelmannii) and unsusceptible (i.e., all other) species. We also assessed the fall direction of the deadwood from the endpoint locations of the longest piece as this can reflect site-level factors driving the spatial arrangement of deadwood including wind direction and topography (Lutz et al. 2020).

\section{Comparison with traditional deadwood sampling methods}

In addition to the explicit mapping deadwood $\geq 10-\mathrm{cm}$ diameter, we installed $1580 \mathrm{~m}$ of planar transects
(Brown's transects) consisting of 79, 20-m transects established between permanent markers (Fig. 1; Brown 1974). We measured surface fuels in four size classes (1 $\mathrm{h}$, less than 0.25 in. $(0.64 \mathrm{~cm})$ in diameter; $10 \mathrm{~h}$, between 0.25 and $1 \mathrm{in}$. (between 0.64 and $2.54 \mathrm{~cm}$ ) in diameter; $100 \mathrm{~h}, 1$ to 3 in. (2.54 to $7.62 \mathrm{~cm}$ ) in diameter; and 1000 $\mathrm{h}$, greater than $3 \mathrm{in} .(7.62 \mathrm{~cm})$ in diameter) as well as litter and duff at ten points on each transect (odd meters from 1 to $19 \mathrm{~m}$ ). These transects, running between the permanent quadrat markers, were sampled in 2019 (Fig. 1). We calculated fuel loading by the methods of Brown (1974) as implemented by Cansler et al. (2019) with additional species data from Woodall and Monleon (2010).

We used a novel method to quantify a portion of the vertical structure of the fuel bed based on the deadwood map. We used the position of individual deadwood polygons (derived from field measurements of large-end and small-end diameters and length; Janík et al. 2018) to develop a "heat-map" depicting the number of intersecting logs which reflected the amount of stacked wood. This provides a map of the three-dimensional structure of surface fuels that may serve as a useful compromise between typical fuel sampling methods (Brown's transects) and more accurate (but expensive and labor intensive) techniques such as ground-based LiDAR. We used the st_intersects() function from the sf package (Pebesma 2018) to count the number of pieces that intersected each piece of deadwood. For the background heatmap, we used the stat_density $2 \mathrm{~d}()$ function from ggplot2 (Wickhan 2016) to perform a kernel density estimation on a point layer generated by placing points at the intersection of two or more pieces of deadwood.

All calculations were performed in $\mathrm{R}$ version 3.6.2 ( $\mathrm{R}$ Core Team 2020) using packages rgdal version 1.4-8 (Bivand et al. 2019), rgeos version 0.5-2 (Bivand and Rundel 2019), sp version 1.3-2 (Pebesma and Bivand 2005), and sf version 0.8-1 (Pebesma 2018).

\section{Results \\ Distribution and spatial orientation of snags and deadwood}

Live tree densities showed both considerable survival of large-diameter Picea engelmannii through the period of the Dendroctonus rufipennis outbreak as well as significant regeneration (Table 1). In 2019, there were 23,598 trees and 4712 snags present (Tables S1, S2). Considering only stems $\geq 10 \mathrm{~cm} \mathrm{DBH}(11,452)$, 25\% were snags (2505). Tabulation of biomass using site-specific equations showed that the large-diameter threshold was 33.2 $\mathrm{cm}$, smaller than the $41.9 \mathrm{~cm}$ threshold derived using generic equations for North America (i.e., Chojnacky et al. 2014; Lutz et al. 2018). Total aboveground live biomass was $1624.6 \mathrm{Mg}\left(119.1 \mathrm{Mg} \mathrm{ha}^{-1}\right)$. There was a total 


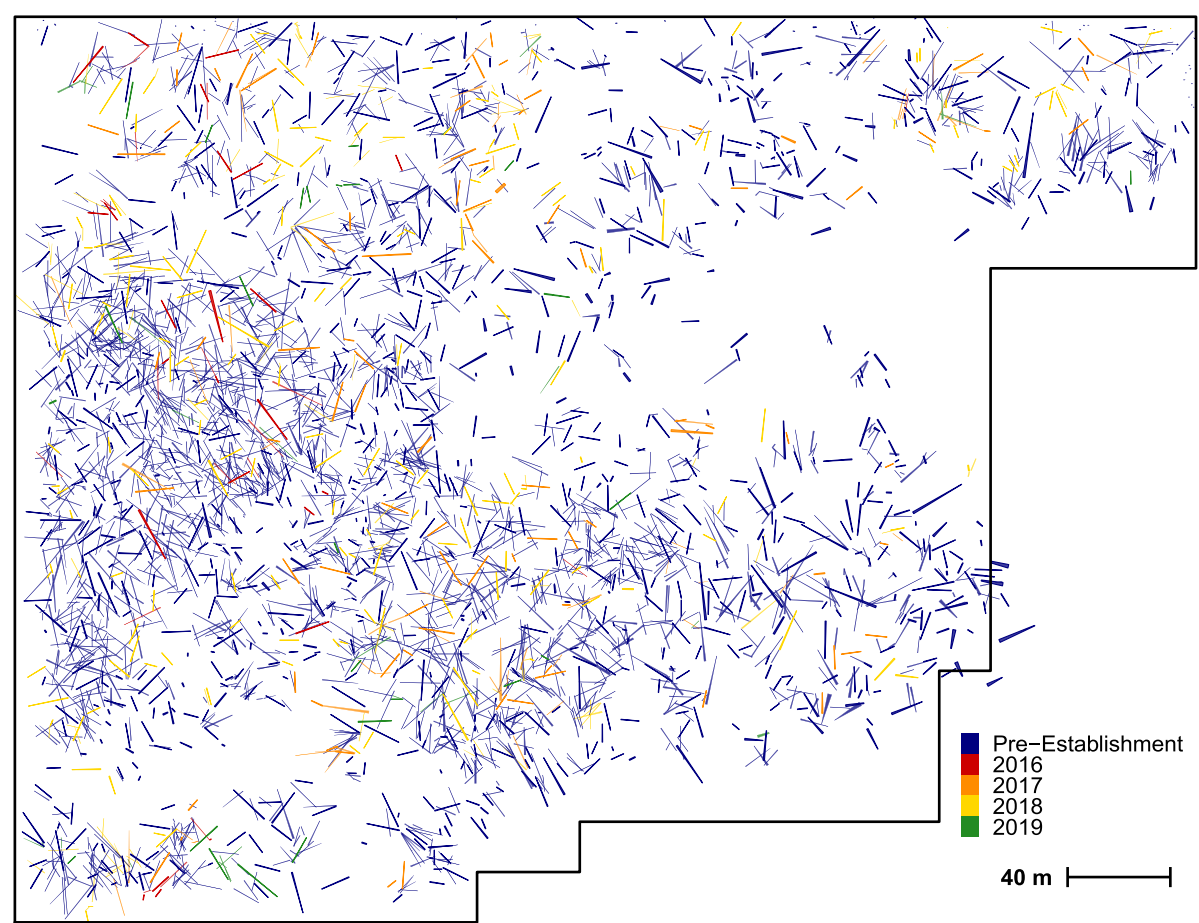

Fig. 2 Annual accumulation of deadwood $\geq 10-\mathrm{cm}$ diameter in 13.64 ha of the Utah Forest Dynamics Plot, as well as deadwood present at the first census in 2015. For annual accumulations by species, see Table S2 and Figs. S2, S3, S4, S5, S6, S7

of 4182 pieces of deadwood originating from 3776 different trees $\geq 10$ - $\mathrm{cm}$ diameter in 13.64 ha (Fig. 2, Table S3). Picea engelmannii represented $17.4 \%$ of deadwood biomass (Table S3), and only $5.7 \%$ of live basal area (Table 1).
Not considering $20 \mathrm{~m} \times 20 \mathrm{~m}$ quadrats where deadwood was absent (generally on the rocky cliffs; Fig. 1), deadwood in $20 \mathrm{~m} \times 20 \mathrm{~m}$ quadrats varied from 0.05 to $154.0 \mathrm{Mg} \mathrm{ha}^{-1}$ (mean of $41.8 \mathrm{Mg} \mathrm{ha}^{-1}$ ). Picea engelmannii deadwood biomass in each $20 \mathrm{~m} \times 20 \mathrm{~m}$ quadrat varied
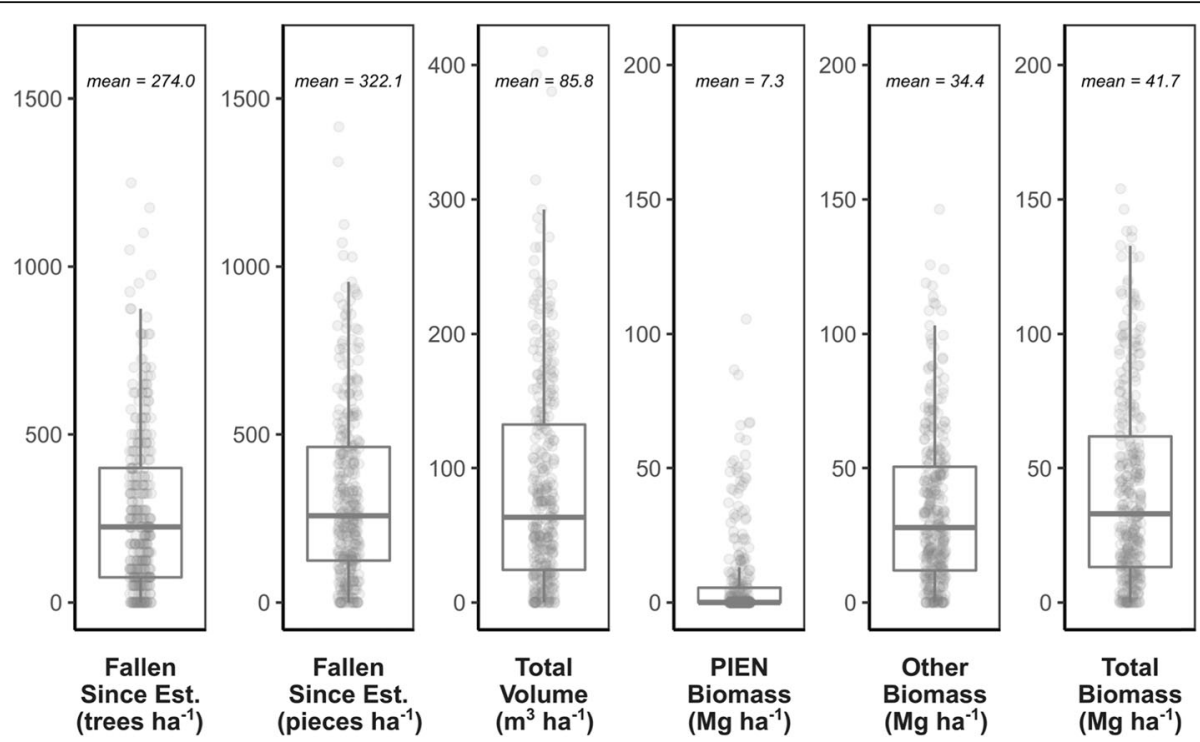

Fig. 3 Spatial variation of deadwood in the Utah Forest Dynamics Plot at the scale of $20 \mathrm{~m} \times 20 \mathrm{~m}$ quadrats. Most trees fell as single pieces. Biomass of Picea engelmannii (PIEN) exceeded that of many other species, but the mean Picea engelmannii biomass was about $20 \%$ of that of other species combined 


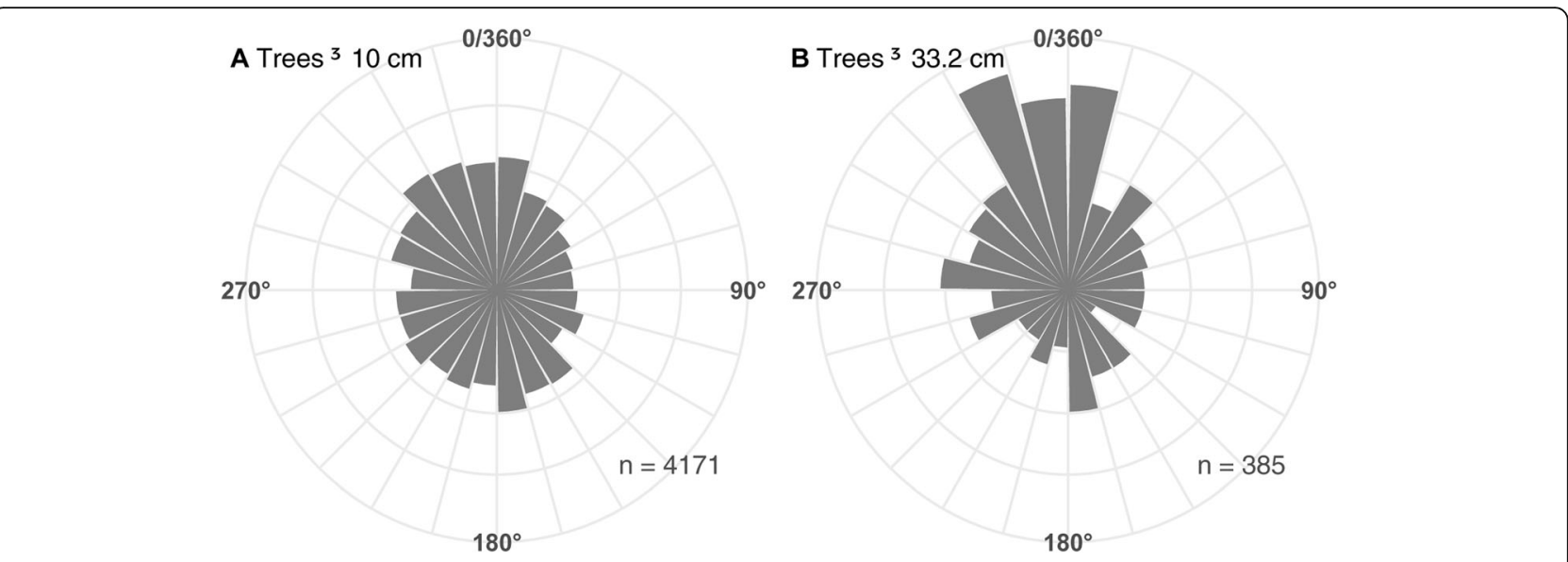

Fig. 4 Directional diagrams of deadwood $\geq 10-\mathrm{cm}$ diameter (a) and large-diameter ( $\geq 33.2 \mathrm{~cm} \mathrm{DBH})$ deadwood (b) in the Utah Forest Dynamics Plot. Each concentric gridline of the rose diagram represents $2 \%$ of the total pieces

from 0.003 to $105.5 \mathrm{Mg} \mathrm{ha}^{-1}$ (mean of $7.3 \mathrm{Mgha}^{-1}$; Fig. 3). Deadwood $\geq 10 \mathrm{~cm}$ did not exhibit strong directionality (Fig. 4a). However, larger diameter deadwood generally fell in northerly directions (Fig. 4b). This directionality most likely reflects the channeling of strong gusts by the local terrain (Fig. 1c). The mean amount of surface fuel measured by planar transects was $62.7 \mathrm{Mg}$ $\mathrm{ha}^{-1}$, but the large wood component $(1000 \mathrm{~h}$ fuels and larger; $\geq 7.62$-cm diameter) was only $31.8 \mathrm{Mg} \mathrm{ha}^{-1}, 75 \%$ of the deadwood mass estimated by explicit measurements.

Annual deposition of deadwood was low compared to the total deadwood pool (Fig. 5). Annual deposition was dominated by smaller diameter classes, with only a few large-diameter trees and snags transitioning to deadwood in each year (Tables S1 and S3, Fig. 5).

\section{Contribution of Picea engelmannii}

The distribution of Picea engelmannii aboveground biomass among live, snag, and deadwood pools differed from that of other species (Figs. 6, S8). For Picea engelmannii, live, snag, and deadwood biomass were approximately equal (7.9 $\mathrm{Mg} \mathrm{ha}^{-1}, 9.8 \mathrm{Mg} \mathrm{ha}^{-1}$, and 7.4 $\mathrm{Mg} \mathrm{ha}^{-1}$, respectively; Fig. 6). For other species as a group, live biomass was about four times snag biomass $(111.2 \mathrm{Mg}$ $\mathrm{ha}^{-1}$ vs. $26.0 \mathrm{Mg} \mathrm{ha}^{-1}$ ), with deadwood biomass slightly exceeding snag biomass at $34.8 \mathrm{Mg} \mathrm{ha}^{-1}$. Compared to other species as a group, Picea engelmannii also showed

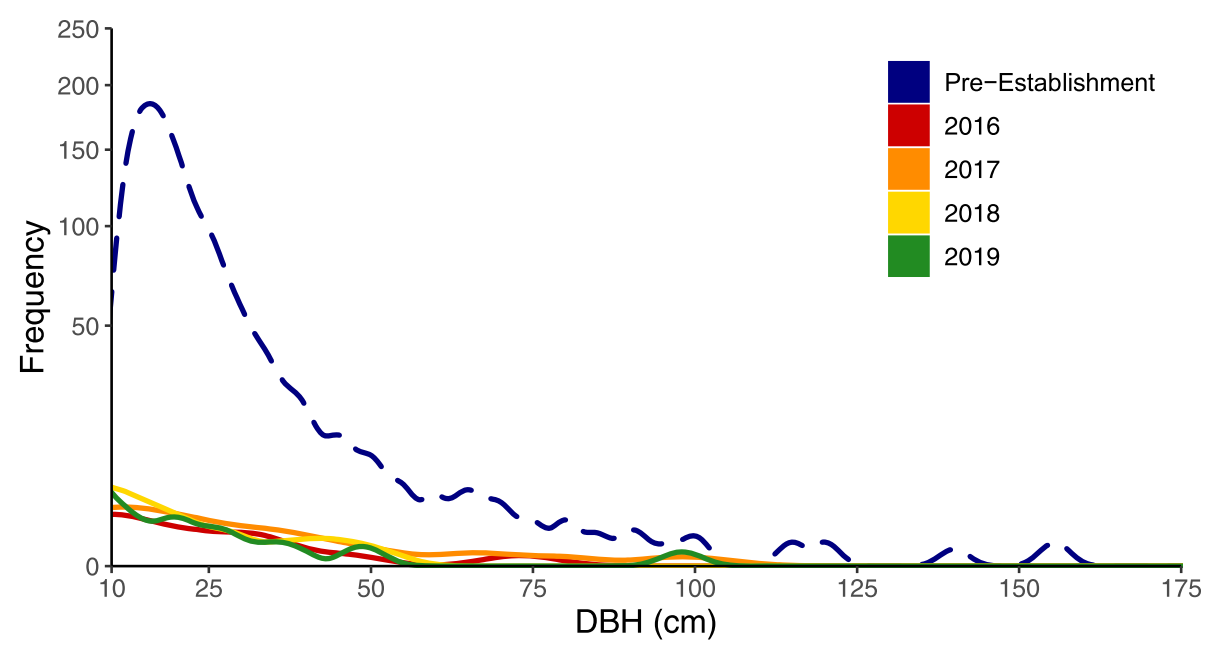

Fig. 5 Diameter distribution of deadwood deposition in the Utah Forest Dynamics Plot in 2016-2019. Pre-establishment refers to deadwood from 2015 and before. Colors correspond to those in Fig. 2. Curves are based on the raw diameter distributions smoothed with a Gaussian density kernel. The square-root transformation of the $y$-axis shows the low frequency but cumulative effects of large-diameter inputs 


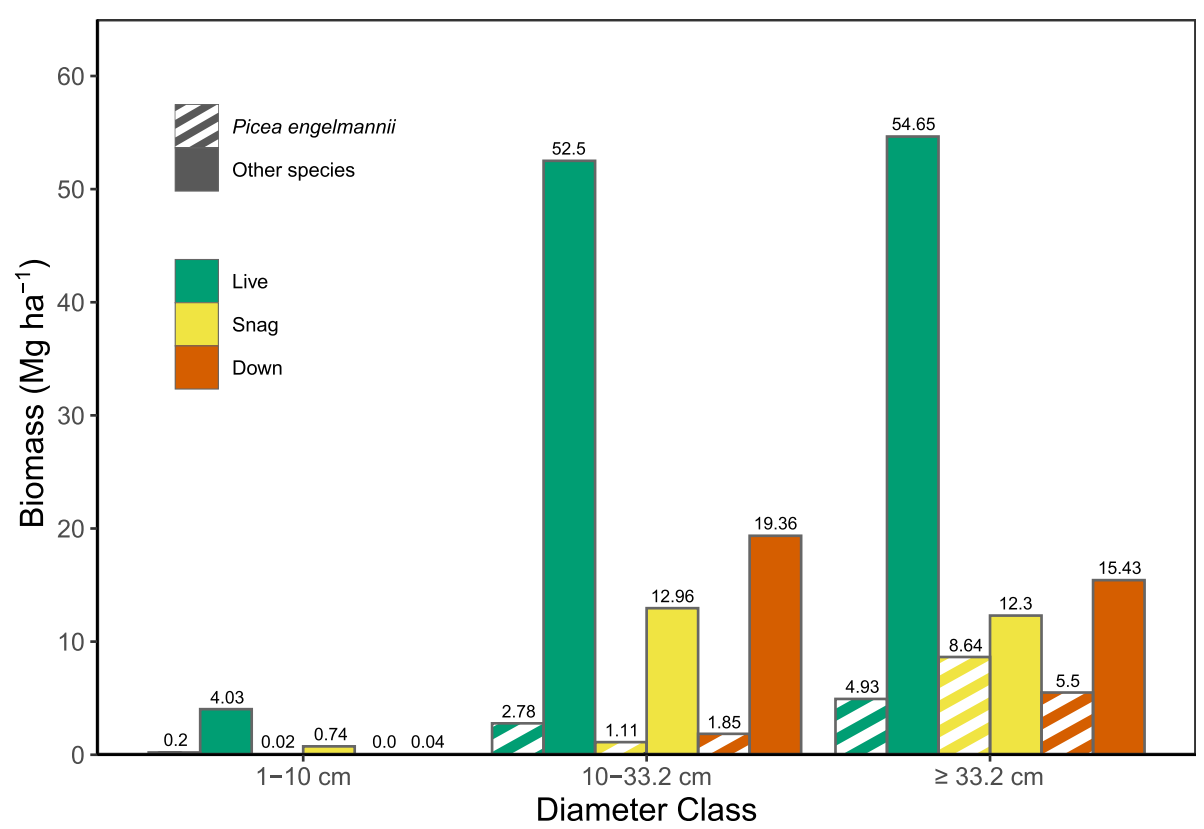

Fig. 6 Division of live tree, snag, and deadwood biomass pools in the Utah Forest Dynamics Plot by diameter class and by susceptibility to Dendroctonus rufipennis (i.e., Picea engelmannii vs. all other species). The diameter division at $33.2 \mathrm{~cm}$ DBH separates living biomass into two equal portions, with 1212 trees $\geq 33.2 \mathrm{~cm} \mathrm{DBH}$ and 22,388 trees $1 \mathrm{~cm} \geq \mathrm{DBH}>33.2 \mathrm{~cm}$. Total live biomass was $119 \mathrm{Mg} \mathrm{ha}^{-1}$, total snag biomass was $36 \mathrm{Mg}$ $\mathrm{ha}^{-1}$, and deadwood biomass was also $42 \mathrm{Mg} \mathrm{ha}^{-1}$. Wood identified as Picea but without designation of species was counted as Picea engelmannii

a higher concentration of biomass in the large diameter class among trees, snags, and deadwood (Fig. 6).

\section{Comparison with traditional planar fuel sampling}

The traditional measurements of large-diameter fuels (Fig. 7d) were significantly less $\left(31.8 \mathrm{Mg} \mathrm{ha}^{-1}\right)$ than estimates from spatially explicit measurements $(41.8 \mathrm{Mg}$ $\left.\mathrm{ha}^{-1}\right)$. Analysis of stacked deadwood showed areas of high vertical fuel structure (Figs. 7 and 8). These areas were usually associated with Picea-Abies-Populus forest communities.

\section{Discussion}

Large-diameter ( $\geq 33.2-\mathrm{cm}$ diameter $)$ snags and deadwood were the principal components of snag and deadwood biomass despite representing only $11 \%$ and $16 \%$ of

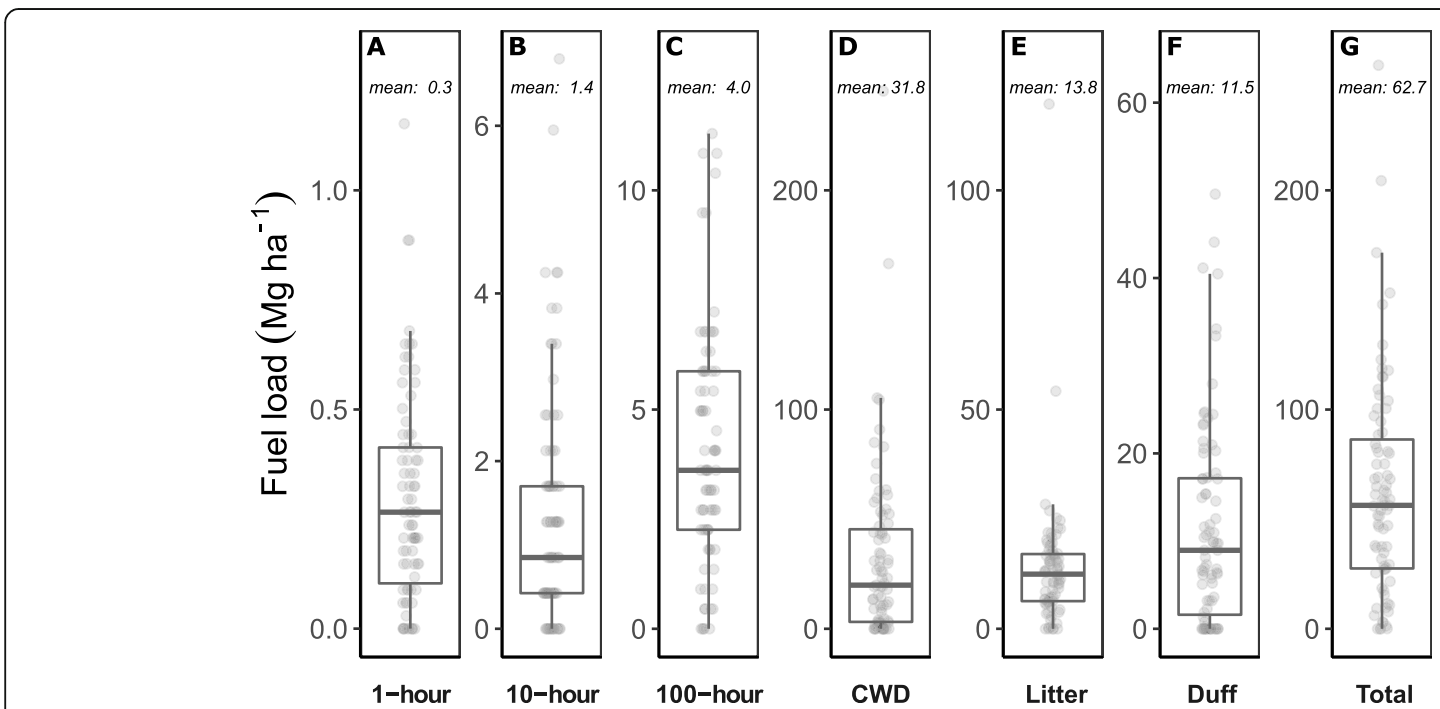

Fig. 7 Fuel loading by fuel category as measured in 79, 20-m planar transects (Brown's transects) in the Utah Forest Dynamics Plot in 2019. CWD-1000-h fuels or larger, defined as $\geq 3$ in. $(7.63 \mathrm{~cm})$ in diameter at the point of line transect interception 

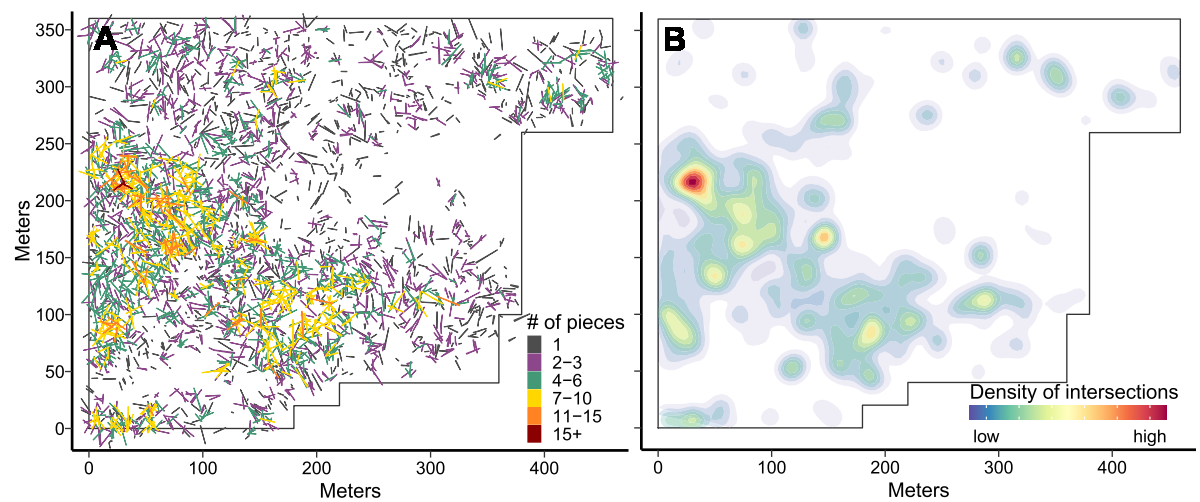

Fig. 8 Vertical structure of surface fuels $\geq 10 \mathrm{~cm}$ diameter in the Utah Forest Dynamics Plot. Deadwood was locally variable in terms of simple biomass (Fig. 2) but also in terms of vertical structure (a). Colors indicate number of pieces of wood "stacked" on each other. The degree of vertical agglomeration was transformed into an intensity diagram (b), with white areas showing no overlap between pieces of deadwood and warmer colors indicating more stacking

pieces, respectively (Fig. 6). Irrespective of species, the concentration of snags and deadwood in the large diameter classes reinforces the ecological significance of largediameter trees even beyond their death (Erb et al. 2016; Körner 2017; Lutz et al. 2018, 2020). The low levels of biomass and productivity of the UFDP compared to temperate forests globally (i.e., Larson et al. 2008; Lutz et al. 2018) and the slower treefall dynamics of beetle mortality as opposed to fire mortality have resulted in a slow development of deadwood in this Picea-Abies forest (Fig. 5).

Within the UFDP, trees killed in the Dendroctonus rufipennis outbreak have not yet become a major contributor to deadwood due to the diverse species assemblage (and hence lower pre-outbreak Picea engelmannii relative abundance; Table 1; Fig. S8). Heterogeneous mixed species stands such as the UFDP appear to have higher resistance to bark beetle outbreaks (Churchill et al. 2013; DeRose and Long 2014). The continued transition of Picea engelmannii snags into deadwood will represent a growing, but still relatively minor component of the overall deadwood within the UFDP. But as drought can hasten the return of both epidemic bark beetle outbreaks and fire (Hart et al. 2014, Sherriff et al. 2001), future climates may see increased mortality (i.e., Lutz et al. 2009) and additional pulses of deadwood.

Fire and epidemic outbreaks of Dendroctonus rufipennis represent two of the principal ecological processes contributing to mortality and deadwood deposition in subalpine spruce-fir forests on the Colorado Plateau (Veblen et al. 1994). As most bark beetles in these forests are specialists on particular host tree species, the ecological effects of bark beetles on forest composition, snags, and deadwood will depend on the prevalence of the host species. In comparison to nearby pure stands of Picea engelmannii that experienced nearly complete overstory mortality (93\%; DeRose and Long 2007), the
UFDP exhibited considerable survivorship and regeneration (Table 1), similar to that seen in mixed-wood forests in other regions that have experienced epidemic Dendroctonus rufipennis outbreaks (Birch et al. 2019a, 2019b; DeRose and Long 2007). The persistence of living large-diameter Picea engelmannii contributes substantially to the overall structural heterogeneity of the forest (sensu Lutz et al. 2013). Standing dead and down Picea engelmannii will also contribute to structural heterogeneity and ecological function for years to come, as long fire return intervals and slow decomposition allow this dead biomass to persist for centuries.

In general, both bark beetle epidemics and fire occur on multi-centennial timescales with local epidemic outbreaks of Dendroctonus rufipennis reoccurring over intervals of approximately 116.5 years and high-severity fire returning every 149-212 years (USDA 2012; Veblen et al. 1994). The data from the UFDP is broadly in line with these estimates, although at the higher end of the range of disturbance return intervals. However, mean return intervals are perhaps less important than the particular sequence of disturbances, their intensities, and intervals between them (Veblen et al. 1994; Becker and Lutz 2016).

\section{Value of explicitly mapping horizontal and vertical deadwood structure}

The spatial heterogeneity of deadwood in the UFDP (Figs. 2, 5, S8) reinforces the importance of modernizing surface fuel field methods (Lutz et al. 2018b), especially when elevated log positions can increase deadwood persistence (Körner 2017). Large-diameter deadwood was a major constituent of fuel stacks, both because of longer lengths and also, presumably, because of slower decomposition rates for deadwood supported off the ground. Actual heterogeneity in surface fuels becomes unexplained variance when using planar sampling methods 
such as Brown's transects, and this variance is ignored when multiple transects are averaged to estimate surface fuel loads among fuel size classes. While planar transects are a useful approximation of the average amount of surface fuels, two- and three-dimensional heterogeneity in surface fuels (Fig. 6b) are fundamental to inferring potential fire behavior (Pimont et al. 2016), especially in small areas where fire behavior may be extreme. This three-dimensional approach to surface fuels may also portend a more efficient way for managers to reduce surface fuels to mitigate fire risk. By understanding the heterogeneity in fuel structure that drives locally high potential flame lengths, fuel reduction, or prescribed fire treatments could focus more resources on less area, potentially maximizing the efficiency of limited time and resources that are available to mitigate fire risk. It also demonstrates that in heterogeneous forests such as this, more targeted salvage logging operations could extract a considerable proportion of available timber while only visiting a small fraction of a stand. This may provide a way to find compromise between the diverse, and often divergent, priorities of local stakeholders.

\section{Conclusions}

Tree mortality and subsequent snagfall have profound consequences for both snag and deadwood biomass, with large-diameter trees dominating biomass dynamics even beyond their death. Outbreaks of species-specific tree mortality agents (such as bark beetles) may have both immediate and delayed effect on deadwood, with the transition to deadwood being quite slow in subalpine environments, especially for large-diameter trees. Lengthy intervals between fires can allow deadwood to accumulate, evident in the high stand-level averages with a long right tail representing exceptionally high amounts of deadwood at local levels. These local maxima contribute diversity to the spatial heterogeneity in habitat and surface fuels, and the vertical stacking of pieces increases airflow which may potentially slow decomposition and lead to longer persistence times.

\section{Supplementary Information}

The online version contains supplementary material available at https://doi. org/10.1186/s13717-020-00275-0.

Additional file 1. Supplementary information.

\footnotetext{
Abbreviations

DBH: Diameter at breast height, $1.37 \mathrm{~m}$ above the forest surface; Deadwood: Down woody debris; here limited to down woody debris $\geq 10$ $\mathrm{cm}$ diameter at its large end. Deadwood does not include litter, duff, or smaller pieces of woody debris that can be important constituents of total surface fuels; Snagfall: When a snag (standing dead tree) falls to the ground leaving a stump $<1.37-m$ tall; Surface fuels: Litter, duff, and woody debris of all diameters as defined and sampled by planar transects according to
}

Brown (1974). Surface fuels include deadwood.; UFDP: Utah Forest Dynamics Plot

\section{Acknowledgements}

The authors thank the field crews who gathered data, each individually acknowledged at http://ufdp.org, and two anonymous reviewers. We thank the managers and staff of Cedar Breaks National Monument for their logistical assistance. We thank The Grind Coffeehouse and Cedar City Library for gratis WiFi access.

\section{Authors' contributions}

JAL conceived the study. JAL, TJF, SS, and JDB performed field work. SS, TJF, and JAL performed analyses. All authors contributed to the writing and read and approved the final manuscript.

\section{Authors' information}

James A Lutz is the principal investigator for the Utah Forest Dynamics Plot, http://ufdp.org; the Yosemite Forest Dynamics Plot, http://yfdp.org; and the Wind River Forest Dynamics Plot, http://wfdp.org, each affiliated with the Smithsonian ForestGEO network, https://forestgeo.si.edu/.

\section{Funding}

Funding was received from the Utah Agricultural Experiment Station (projects 1153 and 1398 to JAL and 1423 to JAL, LLY, and DJM) and the Smithsonian Institution ForestGEO. Research was performed under the National Park Service research permits CEBR-2014-SCI-0001, CEBR-2015-SCI0001, CEBR-2016-SCI-0001, CEBR-2017-SCI-0001, CEBR-2018-SCI-0001, and CEBR-2019-SCI-0001 for study CEBR-00016.

\section{Availability of data and materials}

All data necessary to recreate analyses is available from the corresponding author.

Ethics approval and consent to participate

Not applicable

\section{Consent for publication}

Not applicable

\section{Competing interests}

The authors declare no competing interests.

\section{Author details}

'Department of Wildland Resources, S. J. and Jessie E. Quinney College of Natural Resources, Utah State University, 5230 Old Main Hill, Logan, UT 84322-5230, USA. ${ }^{2}$ Department of Renewable Resources, University of Alberta, Edmonton, Alberta, Canada.

Received: 19 September 2020 Accepted: 30 November 2020 Published online: 11 January 2021

\footnotetext{
References

Anderson-Teixeira KJ, Davies SJ, Bennett AC, Gonzalez-Akre EB, Muller-Landau HC, Wright SJ, Abu Salim K, Baltzer JL, Bassett Y, Bourg NA, Broadbent EN, Brockelman WY, Bunyavejchewin S, Burslem DFRP, Butt N, Cao M, Cardenas D, Clay K, Condit RS, Detto M, Du X, Duque A, Erikson DL, Ewango CEN, Fletcher CD, Gilbert GS, Gunatilleke N, Gunatilleke S, Hao Z, Hargrove WH, Hart TB, Hao B, He F, Hoffman FM, Howe R, Hubbell SP, Jansen PA, Jiang M, Kanzaki M, Kenfack D, Kinnaird MF, Kumar J, Larson AJ, Li Y, Li X, Liu S, Lum SKY, Lutz JA, Ma K, Maddalena D, Makana JR, Malhi Y, Marthews T, McMahon S, McShea WJ, Memiaghe H, Mi X, Mizuno T, Myers JA, Novotny V, de Oliveira AA, Orwig D, Ostertag R, den Ouden J, Parker G, Phillips R, Rahman A, Sringernyuang K, Sukumar R, Sun IF, Sungpalee W, Tan S, Thomas SC, Thomas D, Thompson J, Turner BL, Uriarte M, Valencia R, Vallejo MI, Vicentini A, Vrška T, Wang XH, Wang XG, Weiblen G, Wolf A, Xu H, Yap S, Zimmerman J (2015) CTFS-ForestGEO: a worldwide network monitoring forests in an era of global change. Glob Chang Biol 21(2):528-549 https://doi.org/10.1111/gcb. 12712

Becker KML, Lutz JA (2016) Can low-severity fire reverse overstory compositional change in montane forests of the Sierra Nevada, USA? Ecosphere 7(12): e01484 https://doi.org/10.1002/ecs2.1484
} 
Bentz BJ, Régnière J, Fettig CJ, Hansen EM, Hayes JL, Hicke JA, Kelsey RG, Negrón JF, Seybold SJ (2010) Climate change and bark beetles of the western United States and Canada: direct and indirect effects. BioScience 60(8):602-613 https://doi.org/10.1525/bio.2010.60.8.6

Birch JD, Lutz JA, Hogg EH, Simard SW, Pelletier R, LaRoi GH, Karst J (2019a) Density-dependent processes fluctuate over 50 years in an ecotone forest. Oecologia 191(4):909-918 https://doi.org/10.1007/s00442-019-04534-6

Birch JD, Lutz JA, Hogg EH, Simard SW, Pelletier R, LaRoi GH, Karst J (2019b) Decline of an ecotone forest: 50 years of demography in the southern boreal forest. Ecosphere 10(4):e02698 https://doi.org/10.1002/ecs2.2698

Bishop M, Furniss TJ, Mock KE, Lutz JA (2019) Genetic and spatial structuring of Populus tremuloides in a mixed-species forest of southwest Utah, USA. West North Am Nat 79(1):63-71 https://doi.org/10.3398/064.079.0107

Bivand R, Keitt T, Rowlingson B (2019) rgdal: bindings for the geospatial data abstraction library. R package version 1.4-8. https://CRAN.R-project.org/ package $=$ rgdal

Bivand R, Rundel C (2019) rgeos: interface to geometry engine. R package version 0.5-2. https://CRAN.R-project.org/package=rgeos

Blomdahl EM, Kolden CA, Meddens AJH, Lutz JA (2019) The importance of smal fire refugia in the central Sierra Nevada, California, USA. Forest Ecol Manag 432:1041-1052 https://doi.org/10.1016/j.foreco.2018.10.038

Brown JK (1974) Handbook for inventorying downed woody material. USDA Forest Service General Technical Report INT-16. USDA Forest Service, Intermountain Forest and Range Experiment Station, Ogden

Brown JK (1976) Estimating shrub biomass from basal stem diameters. Can J For Res 6(2):153-158 https://doi.org/10.1139/x76-019

Brown JK (1978) Weight and density of crowns of Rocky Mountain conifers. USDA Forest Service Research Paper INT-RP-197. USDA Forest Service Intermountain Forest and Range Experiment Station, Ogden, p 56

Cansler CA, Swanson ME, Furniss TJ, Larson AJ, Lutz JA (2019) Fuel dynamics after reintroduced fire in an old-growth Sierra Nevada mixed-conifer forest. Fire Ecol 15:16 https://doi.org/10.1186/s42408-019-0035-y

Chojnacky DC, Heath LS, Jenkins JC (2014) Updated generalized biomass equations for North American tree species. Forestry 87:129-151 https://doi. org/10.1093/forestry/cpt053

Churchill D, Larson AJ, Dahlgreen MC, Franklin JF, Hessburg PF, Lutz JA (2013) Restoring forest resilience: from reference spatial patterns to silvicultural prescriptions and monitoring. Forest Ecol Manag 291:442-457 https://doi. org/10.1016/j.foreco.2012.11.007

Cook ER, Seager R, Cane MA, Stahle DW (2007) North American drought: reconstructions, causes, and consequences. Earth-Sci Rev 81(7):91-134 https://doi.org/10.1016/j.earscirev.2006.12.002

DeRose RJ, Bentz BJ, Long JN, Shaw JD (2013) Effect of increasing temperatures on the distribution of spruce beetle in Engelmann spruce forests of the Interior West, USA. Forest Ecol Manag 308:198-206 https://doi.org/10.1016/j. foreco.2013.07.061

DeRose RJ, Long JN (2007) Disturbance, structure, and composition: spruce beetle and Engelmann spruce forests on the Markagunt Plateau, Utah. Forest Ecol Manag 244:16-23 https://doi.org/10.1016/j.foreco.2007.03.065

DeRose RJ, Long JN (2012a) Drought-driven disturbance history characterizes a southern Rocky Mountain subalpine forest. Can J For Res 42(9):1649-1660 https://doi.org/10.1139/×2012-102

DeRose RJ, Long JN (2012b) Factors influencing the spatial and temporal dynamics of Engelmann spruce mortality during a spruce beetle outbreak on the Markagunt Plateau, Utah. For Sci 58(1):1-14 https://doi.org/10.5849/forsci.10-079

DeRose RJ, Long JN (2014) Resistance and resilience: a conceptual framework for silviculture. For Sci 60(6):1205-1212

Donato DC, Fontaine JB, Campbell JL, Robinson WD, Kauffman JB, Law BE (2006) Post-wildfire logging hinders regeneration and increases fire risk. Science 311(5759):352 https://doi.org/10.1126/science.1122855

Erb K-H, Fetzel T, Plutzar C, Kastner T, Lauk C, Mayer A, Niedertscheider M, Körner C, Haberl H (2016) Biomass turnover time in terrestrial ecosystems halved by land use. Nat Geosci 9:674-678 https://doi.org/10.1038/ngeo2782

Flora of North America Editorial Committee, Editors (1993) Flora of North America north of Mexico, vol 20, New York and Oxford

Freund JA, Franklin JF, Larson AJ, Lutz JA (2014) Multi-decadal establishment for single-cohort Douglas-fir forests. Can J For Res 44(9):1068-1078 https://doi. org/10.1139/cjfr-2013-0533

Furniss TJ, Larson AJ, Kane VR, Lutz JA (2020) Wildfire and drought moderate the spatial elements of tree mortality. Ecosphere 11(8):e03214 https://doi.org/10. 1002/ecs 2.3214
Furniss TJ, Larson AJ, Lutz JA (2017) Reconciling niches and neutrality in a subalpine temperate forest. Ecosphere 8(6):Article01847 https://doi.org/10. 1002/ecs 2.1847

Halpern CB, Lutz JA (2013) Canopy closure exerts weak controls on understory dynamics: a 30-year study of overstory-understory interactions. Ecol Monogr 83(2):221-237 https://doi.org/10.1890/12-1696.1

Harmon ME, Fasth B, Woodall CW, Sexton J (2013) Carbon concentration of standing and downed woody detritus: effects of tree taxa, decay class, position, and tissue type. Forest Ecol Manag 291:259-267 https://doi.org/10. 1016/j.foreco.2012.11.046

Harmon ME, Fasth BG, Yatskov M, Kastendick D, Rock J, Woodall CW (2020) Release of coarse woody detritus-related carbon: a synthesis across forest biomes. Carbon Balance Manag 15:1 https://doi.org/10.1186/s13021-0190136-6

Harmon ME, Franklin JF, Swanson FJ, Sollins P, Gregory SV, Lattin JD, Anderson $\mathrm{NH}$, Cline SP, Aumen NG, Sedell JR, Lienkaemper GW, Cromack K Jr, Cummins KW (1986) Ecology of coarse woody debris in temperate ecosystems. Adv Ecol Res 15:133-302 https://doi.org/10.1016/S00652504(08)60121-X

Harmon ME, Woodall CW, Fasth B, Sexton J (2008) Woody detritus density and density reduction factors for tree species in the United States: a synthesis. General Technical Report NRS-29. Northern Research Station, USDA Forest Service, Newton Square, PA

Hart SJ, Veblen TT, Eisenhart KS, Jarvis D, Kulakowski D (2014) Drought induces spruce beetle (Dendroctonus rufipennis) outbreaks across northwestern Colorado. Ecology 95(4):930-939 https://doi.org/10.1890/13-0230.1

Heyerdahl EK, Brown PM, Kitchen SG, Weber MH (2011) Multicentury fire and forest histories at 19 sites in Utah and eastern Nevada. Gen. Tech. Rep. RMRSGTR-261WWW. U.S. Department of Agriculture, Forest Service, Rocky Mountain Research Station, Fort Collins

Hiers JK, O'Brien JJ, Mitchell RJ, Grego JM, Loudermilk EL (2009) The wildland fuel cell concept: an approach to characterize fine-scale variation in fuels and fire in frequently burned longleaf pine forests. Int J Wildland Fire 18(3):315-325 https://doi.org/10.1071/WF08084

Hudak AT, Kato A, Bright BC, Loudermilk EL, Hawley C, Restaino JC, Ottmar RD, Prata GA, Cabo C, Prichard SJ, Rowell EM, Weise DR (2020) Towards spatially explicit quantification of pre- and postfire fuels and fuel consumption from traditional and point cloud measurements. For Sci 66(4):428-442 https://doi. org/10.1093/forsci/fxz085

Janík D, Král K, Adam D, Vrška T, Lutz JA (2018) Smithsonian ForestGEO Dead Wood Census Protocol. Utah State University Digital Commons Paper 76. https://doi.org/10.26078/vcdr-y089

Janisch JE, Harmon ME (2002) Successional changes in live and dead wood carbon stores: implications for net ecosystem productivity. Tree Physiol 22(23):77-89 https://doi.org/10.1093/treephys/22.2-3.77

Jenkins JC, Chojnacky DC, Heath LS, Birdsley RA (2003) National scale biomass estimators for United States tree species. For Sci 49(1):12-35 https://doi.org/ 10.1016/j.foreco.2012.02.036

Jeronimo SMA, Lutz JA, Kane VR, Larson AJ, Franklin JF (2020) Burn weather and three-dimensional fuel structure determine post-fire tree mortality. Landsc Ecol 35:859-878 https://doi.org/10.1007/s10980-020-00983-0

Kolden CA, Abatzoglou JT, Lutz JA, Cansler CA, Kane JT, van Wagtendonk JW, Key $\mathrm{CH}$ (2015) Climate contributors to forest mosaics: ecological persistence following wildfire. Northwest Sci 89(3):219-238 https://doi.org/10.3955/046. 089.030

Kolden CA, Lutz JA, Key CH, Kane JT, van Wagtendonk JW (2012) Mapped versus actual burned area within wildfire perimeters: characterizing the unburned. Forest Ecol Manag 286:38-47 https://doi.org/10.1016/j.foreco.2012.08.020

Körner C (2017) A matter of tree longevity. Science 355(6321):130-131 https://doi. org/10.1126/science.aal2449

Larson AJ, Lutz JA, Gersonde RF, Franklin JF, Hietpas FF (2008) Productivity influences the rate of forest structural development. Ecol Appl 18(4):899-910 https://doi.org/10.1890/07-1191.1

Loudermilk EL, O'Brien JJ, Mitchell RJ, Cropper WP, Hiers JK, Grunwald S, Grego J, Fernandez-Diaz JC (2012) Linking complex forest fuel structure and fire behaviour at fine scales. Int J Wildland Fire 21:882-893 https://doi.org/10.1071/WF10116

Lutz JA (2015) The evolution of long-term data for forestry: large temperate research plots in an era of global change. Northwest Sci 89(3):255-269 https://doi.org/10.3955/046.089.0306

Lutz JA, Furniss TJ, Germain SJ, Becker KML, Blomdahl EM, Jeronimo SMA, Cansler CA, Freund JA, Swanson ME, Larson AJ (2017a) Shrub communities, spatial 
patterns, and shrub-mediated tree mortality following reintroduced fire in Yosemite National Park, California, USA. Fire Ecol 13(1):104-126 https://doi. org/10.4996/fireecology.1301104

Lutz JA, Furniss TJ, Johnson DJ, Davies SJ, Allen D, Alonso A, Anderson-Teixeira K, Andrade A, Baltzer J, Becker KML, Blomdahl EM, Bourg NA, Bunyavejchewin S, Burslem DFRP, Cansler CA, Cao K, Cao M, Cárdenas D, Chang L-W, Chao K-J, Chao W-C, Chiang J-M, Chu C, Chuyong GB, Clay K, Condit R, Cordell S, Dattaraja HS, Duque A, Ewango CEN, Fisher GA, Fletcher C, Freund JA, Giardina C, Germain SJ, Gilbert GS, Hao Z, Hart T, Hau BCH, He F, Hector A, Howe RW, Hsieh C-F, Hu Y-H, Hubbell SP, Inman-Narahari FM, Itoh A, Janík D, Kassim AR, Kenfack D, Korte L, Král K, Larson AJ, Li Y-D, Lin Y, Liu S, Lum S, Ma K, Makana J-R, Malhi Y, McMahon SM, McShea WJ, Memiaghe HR, Mi X, Morecroft M, Musili PM, Myers JA, Novotny V, de Oliveira A, Ong P, Orwig DA, Ostertag R, Parker GG, Patankar R, Phillips RP, Reynolds G, Sack L, Song G-ZM, Su S-H, Sukumar R, Sun I-F, Suresh HS, Swanson ME, Tan S, Thomas DW, Thompson J, Uriarte M, Valencia R, Vicentini A, Vrška T, Wang X, Weiblen GD, Wolf A, Wu S-H, Xu H, Yamakura T, Yap S, Zimmerman JK (2018) Global importance of large-diameter trees. Glob Ecol Biogeogr 27(7):849-864 https://doi.org/10.1111/geb.12747

Lutz JA, Halpern CB (2006) Tree mortality during early forest development: a long-term study of rates, causes, and consequences. Ecol Monogr 76(2):257275 https://doi.org/10.1890/0012-9615(2006)076[0257:TMDEFD]2.0.CO;2

Lutz JA, Larson AJ, Freund JA, Swanson ME, Bible KJ (2013) The importance of large-diameter trees to forest structural heterogeneity. PLOS ONE 8(12): e82784 https://doi.org/10.1371/journal.pone.0082784

Lutz JA, Larson AJ, Swanson ME (2018b) Advancing fire science with large forest plots and a long-term multidisciplinary approach. Fire 1(1):5 https://doi.org/ 10.3390/fire1010005

Lutz JA, Larson AJ, Swanson ME, Freund JA (2012) Ecological importance of large-diameter trees in a temperate mixed-conifer forest. PLoS ONE 7(5): e36131 https://doi.org/10.1371/journal.pone.0036131

Lutz JA, Matchett J, Tarnay L, Smith D, Becker KML, Furniss TJ, Brooks M (2017b) Fire and the distribution and uncertainty of carbon sequestered as aboveground tree biomass in Yosemite and Sequoia \& Kings Canyon National Parks. Land 6:10 https://doi.org/10.3390/land6010010

Lutz JA, Struckman S, Furniss TJ, Cansler CA, Germain SJ, Yocom LL, McAvoy DJ, Kolden CA, Smith AMS, Swanson ME, Larson AJ (2020) Large-diameter trees dominate snag and surface biomass following reintroduced fire. Ecol Process 9:41 https://doi.org/10.1186/s13717-020-00243-8

Lutz JA, van Wagtendonk JW, Franklin JF (2009) Twentieth-century decline of large-diameter trees in Yosemite National Park, California, USA. Forest Ecol Manag 257(11):2296-2307. https://doi.org/10.1016/j.foreco.2009.03.009

Means J, Hansen H, Koerper G, Alaback P, Klopsch M (1994) Software for computing plant biomass - BIOPAK users guide. USDA Forest Service General Technical Report PNW-GTR-340. USDA Forest Service Pacific Northwest Research Station, Portland, Oregon.

Meddens AJH, Kolden CA, Lutz JA, Abatzoglou J, Hudak A (2018b) Spatiotemporal patterns of unburned areas within fire perimeters in the northwestern United States from 1984 to 2014. Ecosphere 9(2):e02029 https://doi.org/10.1002/ecs2.2029

Meddens AJH, Kolden CA, Lutz JA, Smith AMS, Cansler CA, Abatzoglou J, Meigs G, Downing W, Krawchuk M (2018a) Fire refugia: what are they and why do they matter for global change? BioScience 68(12):944-954 https://doi.org/10. 1093/biosci/biy103

Miller C, Urban DL (2000) Connectivity of forest fuels and surface fire regimes. Landsc Ecol 15:145-154 https://doi.org/10.1023/A:1008181313360

Pebesma EJ (2018) Simple features for R: standardized support for vector data. R J 10(1):439-446 https://doi.org/10.32614/RJ-2018-009

Pebesma EJ, Bivand RS (2005) Classes and methods for spatial data in R. R News 5(2) https://cran.r-project.org/doc/Rnews/

Pimont F, Parsons R, Rigolot E, de Coligny F, Dupuy J-L, Dreyfus P, Linn RR (2016) Modeling fuels and fire effects in 3D: model description and applications. Environ Model Softw 80:225-244 https://doi.org/10.1016/j.envsoft.2016.03.003

Povak N, Churchill D, Cansler CA, Hessburg PF, Kane VR, Kane JT, Lutz JA, Larson AJ (2020) In Press. Wildfire severity and post-fire salvage harvest effects on long-term forest regeneration. Ecosphere 11(8):e03199 https://doi.org/10. 1002/ecs2.3199

Privetivy T, Adam D, Vrška T (2018) Decay dynamics of Abies alba and Picea abies deadwood in relation to environmental conditions. Forest Ecol Manag 427: 250-259 https://doi.org/10.1016/j.foreco.2018.06.008
R Core Team (2020) A language and environment for statistical computing. $R$ Foundation for Statistical Computing, Vienna https://www.R-project.org

Réjou-Méchain M, Muller-Landau HC, Detto M, Thomas SC, Le Toan T, Saatchi SS, Silva JSB, Bourg NA, Bunyavejchewin S, Butt N, Brockelman WY, Cao M, Cárdenas D, Chiang JM, Chuyong GB, Clay K, Condit R, Dattaraja HS, Davies SJ, Duque A, Esufali S, Ewango C, Fernando S, Fletcher CD, Gunatilleke IAUN, Hao Z, Harms KE, Hart TB, Hérault B, Howe RW, Hubbell SP, Johnson DJ, Kenfack D, Larson AJ, Lin L, Lin Y, Lutz JA, Makana JR, Malhi Y, Marthews TR, McEwan RW, McMahon SM, McShea WJ, Muscarella R, Nathalang A, Nytch CJ, Oliveira AA, Phillips RP, Pongpattananurak N, Punchi-Manage R, Salim R, Schurman J, Sukumar R, Noor NS b M, Suresh HS, Suwanvecho U, Thomas DW, Thompson J, Uríarte M, Valencia R, Vicentini A, Wolf AT, Yap S, Yuan Z, Zartman CE, Zimmerman JK, Chave J (2014) Local spatial structure of forest biomass and its consequences for remote sensing of carbon stocks. Biogeosciences 11:6827-6840. https://doi.org/10.5194/bg-11-6827-2014

Romme WH, Floyd ML, Hanna D (2009) Historical range of variability and current landscape condition analysis: South Central Highlands section, Southwestern Colorado and Northwestern New Mexico. Colorado Forest Restoration Institute at Colorado State University and USDA Forest Service, Fort Collins

Sherriff RL, Veblen TT, Sibold J (2001) Fire history in high elevation subalpine forests in the Colorado Front Range. Ecoscience 8(3):369-380 https://doi.org/ 10.1080/11956860.2001.11682665

Stenzel JE, Bartowitz KJ, Hartman MD, Lutz JA, Kolden CA, Smith AMS, Swanson ME, Larson AJ, Parton WJ, Hudiburg TW (2019) Fixing a snag in carbon emissions estimates from wildfires. Glob Chang Biol 25(11):3985-3994 https://doi.org/10.1111/gcb.14716

Taborska M, Privetivy T, Vrška T, Odor P (2015) Bryophytes associated with two tree species and different stages of decay in a natural fir-beech mixed forest in the Czech Republic. Preslia 87:387-401 http://www.preslia.cz/P154 Taborska.pdf

Thorn S, Seibold S, Leverkus AB, Michler T, Müller J, Noss RF, Stork N, Vogel S, Lindenmayer DB (2020) The living dead: acknowledging life after tree death to stop forest degradation. Front Ecol Environ 18(9):505-512 https://doi.org/ 10.1002/fee.2252

U.S. Department of Agriculture, Forest Service, Missoula Fire Sciences Laboratory (2012) Information from LANDFIRE on fire regimes of Great Basin subalpine mixed-conifer communities. In: Fire effects information system, [Online], U.S. Department of Agriculture, Forest Service, Rocky Mountain Research Station, Missoula Fire Sciences Laboratory (Producer) Available: http://www.fs.fed.us/ database/feis/fire_regimes/GB_subalpine_mixed_conifer/all.html Downloaded 3 August 2020

Veblen TT, Hadley KS, Nel EM, Kitzberger T, Reid M, Villalba R (1994) Disturbance regime and disturbance interactions in a Rocky Mountain subalpine forest. J Ecol 82:125-135 https://doi.org/10.2307/2261392

Vrška T, Privetivy T, Janík D, Unar P, Samonil P, Král K (2015) Deadwood residence time in alluvial hardwood temperate forests - a key aspect of biodiversity conservation. Forest Ecol Manag 357:33-41 https://doi.org/10.1016/j.foreco. 2015.08 .006

Wickhan H (2016) ggplot2: elegant graphics for data analysis. Springer-Verlag, New York, p 276

Woodall CW, Monleon VJ (2010) Estimating the quadratic mean diameters of fine woody debris in forests of the United States. Forest Ecol Manag 260:10881093 https://doi.org/10.1016/j.foreco.2010.06.036

\section{Publisher's Note}

Springer Nature remains neutral with regard to jurisdictional claims in published maps and institutional affiliations. 